\title{
Schoolfailure, Why?
}

\author{
Rubén Herrero Carrasco", Vicente Morales Baños ${ }^{2}$, Arturo Díaz Suarez, ${ }^{2, *}$ \\ ${ }^{1}$ Master's student, UCAM \\ ${ }^{2}$ Faculty of Sport Sciences, University of Murcia, Murcia, España \\ *Corresponding author: ardiaz@um.es
}

Received November 20, 2014; Revised December 15, 2014; Accepted December 25, 2014

\begin{abstract}
Reducing the school failure is a challenge that the Spanish educational system has to deal with everyday. Various causes and variables affect the school failure but not all of them are intrinsic to the student. The detection and evaluation of these causes will provide us with the necessary information to diagnose the problem and to prevent the "future" school failure of the student. Family, academic and personal determinants are some of the variables we have to take into account when interceding in this multidimensional problem. High-performance educational systems in countries of the OECD are those that mix quality and equity. The better the economy was in Spain (housing bubble), the more opportunities this students had to get an easy way out in a non qualified job, however, societies with well qualified people are better prepared for the actual crisis and the future ones.
\end{abstract}

Keywords: education in values, violence, students

Cite This Article: Rubén Herrero Carrasco, Vicente Morales Baños, and Arturo Díaz Suarez, "Schoolfailure, Why?.” American Journal of Sports Science and Medicine, vol. 2, no. 6A (2014): 1-4. doi: 10.12691/ajssm-2-6A-1.

\section{Introduction}

"The quality of an educational system of a country is not only a sign of the development and welfare level reached, but also the coming ones" [1]. At school, students abandon the family sphere's behavior in order to achieve a full and a no troubled incorporation in the labor market.

School failure is the biggest challenge the Spanish educational system has to confront considering that it questions its inner efficiency (students' performance) and external one (students' failure when entering in the labor market and in the society) [2].

Reducing the school failure has great benefits for the society and the individuals. It can also contribute to the economic growth and the social development. In fact, the educational systems with the highest performance in OECD countries are those that combine quality and equity [3].

But, what is the school failure? Is it a low performance student? Is it a student who does not finish the obligatory education? Is it a student who quit? OECD consider both a student who does not achieve the minimum acknowledge and a student who does not finish the high school as school failure.

In Spain, both percentage of population with general orientation studies and percentage of population with career guidance studies are low compared to the rest of countries analyzed. This could be explained with the high number of persons that do not finish the high school (school failure) and, therefore, the non-continuation of the student in their general orientation studies or career guidance studies, in addition to those students that start their studies but do not finish them [4].
Currently, even the students that conclude theobligatory education may not have guarantee the necessary competences to confront an economy with more and more qualification and the existence of a constant labor flexibility”

\section{Causes of School Failure}

"The blame of school failure does not only lies in the student body but also in the way the faculty organize the institute and establish the educational answer to problems" [5].

"Intrinsic causes of the student have been usually pointed as causes of school failure, but extrinsic ones are getting more and more pointed, making reference to extern incitement that could determine the behavior of the student, therefore it could condition the school failure" [6].

Besides, it is important to dismiss the explanations that only take into account just a part of the whole problem as source of school failure, for instance, just the socials differences or the school organization. Multidimensional explanations are recommended by experts.

Actually, several studies that attempt to explain school failure are based on the tree elements that take part in education: family, academic and personal determinants [7]. But others elements like public spending, the level of the school and the class, or even, the teacher's personality are decisive in school efficiency.

\section{Detection, Evaluation, Diagnosis and Prevention}


When trying to determinate the school failure we have topay attention to some variables or determinants that affect the efficiency of the student. In this way, we will be able to asses and diagnose the situation and, finally, we will be able to prevent the "future" failure. In this section, some variables of the three elements we have established before and that take part in school failure are going to be fixed.

The motivation oriented toward a goal and the autoconcept are two personal important variables that take part in the school efficiency. Actually, there are lots of them, for instance, the distraction with new technologies. The goal's theory is a hot topic inside the debate of school efficiency where we can get to know the performance of the student in the classroom depending on the kind of goal they pursue. According to De La Fuente (2002), the goal's theory has become an great stimulus in the range school motivation, but there are some inconsistencies to deal with in the future. Besides, the study of the goal of the students have been divert towards the study of the academic ones instead of the social ones.

The academic autoconcept is the base of the future of the school and the school failure, starting to appear since pre-school education from contact with equals and the attitude and expectations of the teacher [7]. If the rest of the class think about the kid as the naughty boy, this kid is going to try to maintain his status, the same happens on the contrary, if the kid is seen as the studious boy he will try to affirm his social status in the class.

Furthermore, repeating the course is use to be the solution applied in a systematical way in Spainfor those students that do not reach a certain academic level apart from the fact that it is said to be an useless way of increase the academic efficiency.

"Regarding to the sex impact, women usually get a high average of performance, that is why, they have a smaller risk of school failure” [2]. This can be related to De La Fuente's study (2002), where he mention that female students are associated with learning and social goals, whereas male students are associated with efficiency ones.

When Suárez (2011) analyzed how the family acts about school failure in the perspective of the Education's Psychology, he set some variables with a different influence according to their own nature. Here there are some of them:

a. The structure and configuration of the family, that is, the number of members that it is formed by and the place the children take up on it.

b. Origen or social class (occupation and social status of the parents, incomings, atmosphere, sociocultural environment and the place of residence's characteristics). The more unfavorable circumstances of life, the more difficulties to confront the educational development of the child. This theory wasn't able to explain why two children with the same parents, having the same high or low cultural capital, could get different marks, one of them fails and the other gets good results. [9].

c. Educational atmosphere in the family. It is included both the parent's attitude about their children studies and the affective environment in which the children grow, next to the expectation of the parents in the children.
Finally, the educational system's running has a great influence on the educative inequality. The resources existing, the support to the families, the admission criteria of the school, the number of student per class, the training and motivation of the teachers, the facilities provided to the students to carry on their studies, the classroom's equipment, the assessment criteria, are general conditions connected with the schooling rate and the student's results. The influence of the educational system cannot lead to forget about the specific responsibility of the schools and teachers in order to reduce the inequalities [10]

In Arnaiz's study (2005) in the Region of Murcia, the datum extracted referred to school failure of cultural minority students show that the gypsy ethnic group of students fail in a majority way in primary school, while maghrebi students fail both in primary school and secondary school.

\section{Educational Intervention}

School failure is a complex and changeable concept. This concept has to be constantly checked in order to allow us to appreciate its multidimensional difficulties that may appear caused by its own nature (11). As we have mentioned before, the school failure's problem can't be analyzed since an one-dimensional perspective, but we have to take into account several dimensions of the different elements.

"If we look back in history, it is easy to appreciate that what it has been set and certificate as school failure in each social, cultural and educative context have been not a fixed idea, but, quite the opposite, a changeable concept" [12]. Or, it is possible to require a nowadays child the same acknowledge than a 60's child?

"The XXI's school has to deal with big challenges. One of them is closely linked to cultural and linguistic diversity" [5].

The educational systems with more efficiency in OECD countries are those that mix quality and equity. Equity related to education means that the personal and social circumstances; like genre, ethnic origin or familiar antecedents; do not obstruct the achievement of the educative potential (justice) and that all the individuals accomplish at least the minimum level of competences (integration) [4].

Once an equal accessit is guaranteed, a similar educative program is provided to all of the students and, as a consequence, the fact that the students who come from low social classes are mainly represented in less valuated programs (both social and academically): special classes, compensational programs is avoided [10].

In OECD's countries [4], almost one of each five students does not achieve a minimum basic level of competences to work in our current society (indicative of lack of social inclusion). In those countries where the educative models are intercultural and are based on equality and recognition, the social inclusion is easier to achieve [5].

\section{Discussion and Conclusions}


After the denomination of "school failure" are hidden a series of particular and universal phenomenon; regrettable levels of investment, low incomes, deficient study condition, lack of teaching resource, weak educational politics, cultural deficiencies in the families, differences in scholar position of the students, etcetera [9].

When the real state bubble was in Spain, those students had a fast way out to the labor market working in nonqualified jobs. But, currently, these students who quit the compulsory education early can find themselves in a very negative situation, with no future expectative.

"Students who not even finish their compulsory education have difficulties lately in their labor incorporation; they usually hold less stable jobs and receive less remuneration” [6].

OECD (2013) mention that people with longer education contribute to more democratic societies and more sustainable economies, furthermore, they are less dependent to public assistance and they are also less vulnerable to economic contractions. Societies with qualified people are better prepared to answer the actual crisis and the possible future ones.

This fact should make the politicians understand the importance of invest in education and investigation. It should be taken as a fundamental agent when getting out of the crisis.

"Since high rates of school failure complicate the step from formal equally opportunities in the educational access, to the guarantee of wide-range concepts of equally opportunities in education" [2].

If we are able to create models of inclusive schools, where multiculturalism is promoted, where each person could satisfy his necessities and inquisitiveness, etc., we will be able to battle the school failure.

\section{Personal Reflection}

A clear concept of School Failure does not exist. In scientific literature there are several definitions, but authors does not agree in accept one of them. Also, this literature is focused on differentiate the different causes of school failure, but, in my view, there are few authors that really talk about possible solutions for teachers like us in order to carry them out.

School failure's problem is serious, since these students finish without the necessary abilities to manage themselves in the labor market in a qualified job. Therefore, these students will need to reluctantly accept a manual and low-skilled labor, with no autonomy and low paid. Adding also the current labor situation that the country is going throw, in which it is being unable to create employment even for qualified people.

Spanish educational system is in constant change and gives rise to disappointed teachers and less and less selfemployed are able to get involved in the TeachingLearning project. Because when they get to adapt them to one system, it immediately changes into another different; and negatives and pessimistic phrases take place and are transmitted to the students.

Apart from that, school has not been able to adapt to new technologies and it has lost the monopoly of knowledge. In the past, students could only learn and get information at schools. At present, TIC's provide children with all kind of information. Teachers must get used to them and also be able to organize that information and transmit the knowledge to their student since a new perspective. Although, tools as Internet have become in another source of inequality among students because while some of them are able to access to the information just clicking, others aren't able to do it so easily.

The draft law (LOMCE) about Education is going to be approved by the administration In order to enter into force will expand the basic education with Basic Professional Training. This Professional Training must be of superior quality, train the student for his labor insertion or for him to continue his studies. But, if these students decide they want to enter the market labor, there must be jobs for them. Currently, the problem lies on the impossibility of finding a job, opening in front of them a very negative future.

At last, in my opinion, analyzing the situation of the currently education system, we must put clear measures to school failure. But including all the determinations as we have seen before: about the academic ones, trying to increase the student's motivation, the learning attitude, the autoconcept, etc.; about the families, making themaware about the importance of their implication in their child's education, guiding their child's behavior at home, or even, training the parents about the importance of the cultural capital, etc.; and about the Educational Centre and teachers, offering them a constant training about Emotional Intelligence and other factors that take part in academic efficiency, besides, these will offer the students several options about carrying on their education, offering support classes, advising, etc.

\section{References}

[1] Fernández, M., Mena, L. andRiviere, J.,Fracaso y abandono escolar en España. Obra Social, Fundación la Caixa. 2010.

[2] Choi, Á., and Calero, J., "Determinantes del riesgo de fracaso escolar en España en PISA-2009 y propuestas de reforma”. Revista de educación. Madrid, 2013, n. 362, septiembre-diciembre; p. 562-593. 2013.

[3] OCDE. "Equity and Quality in Education (Summary in Spanish). Supporting Disadvantaged Students and School”. OECD Publishing. Pages: 168. ISBN: 9789264130852.

[4] Organización para la Cooperación y el Desarrollo Económico OCDE."Panorama de la educación, Indicadores de la OCDE 2013, Informe Español”. http://www.mecd.gob.es/inee. 2013.

[5] Arnaiz, P., "Fracaso escolar del alumnado perteneciente a grupos culturales minoritarios en la Región de Murcia? La realidad educativa en las etapas de educación primaria y secundaria”. Anales de Historia Contemporánea (No. 21, pp. 95-110). Servicio de Publicaciones. 2005

[6] Suárez, N., Tuero-Herrero, E., Bernardo, A., Fernández, E., Cerezo, R., González-Pienda, A.,Rosário, P., and Núñez, J. C., "El fracaso escolar en Educación Secundaria”. Magister: Revista miscelánea de investigación, 24, 49-64. 2011.

[7] Lozano, A.,"Factores personales, familiares y académicos que afectan al fracaso escolar en la Educación Secundaria”. Electronicjournal of research in educationalpsychology, 1 (1), 4366. 2003.

[8] De la Fuente, J., "Perspectivas recientes en el estudio de la motivación: la teoría de la orientación de la meta”. Escritos de psicología, (6), 72-84. 2002.

[9] Zambrano, A.,"Relación con el saber, fracaso/éxito escolar y estrategias de enseñanza-aprendizaje”. Actualidades Pedagógicas. 2013.

[10] Marchesi, A., "Un sistema de indicadores de desigualdad educativa”. Revista iberoamericana de Educación, (23), 135-164. 2000 . 
[11] Grau, R and Sancho, C.,"Diseño y validación de un cuestionario sobre fracaso escolar en alumnado de educación secundaria de un centro de formación de personas adultas”. Actualidades Investigativas en Educación, 13 (1), 267-291. 2013.
[12] Escudero, J. M., "Fracaso escolar, exclusión educativa: de qué se excluye ycómo?", en Profesorado, Revista de Currículo y Formación del Profesorado, vol.9, n. ${ }^{\circ}$ 1. 2005 [Online]. Available: http://www.ugr.es/ recfpro/rev91ART1.pdf. [Accessed Dec. 2, 2004] 